\title{
SENSE OF PLACE KOTA BOGOR BERDASARKAN PERSEPSI PENDUDUK DI TIGA TIPOLOGI PERMUKIMAN \\ (Sense of Place of Bogor city based on Community Perception in three typologies of Settlements)
}

Agus Dharma Tohjiwa

Jurusan Arsitektur Universitas Gunadarma

Jl. Margonda Raya 100 Depok

agus_dh@staff.gunadarma.ac.id

\begin{abstract}
Bogor city has three typologies of settlements that are historical area, internal development area and commuting area. The purpose of this study is to describe the sense of place in the city of Bogor based on the perception of the resident living in those settlements. This research uses a survey method using questionnaire and field observations. Research variables using three components of sense of place which are physical attributes, activities, and conception. The result shows that the natural conditions and colonial heritage still has a major contribution in creating Bogor's sense of place. Activity as a commuter from Bogor to Jakarta is the main activity characteristics in this city. Nevertheless, at the weekend most people spend time in their own city. Most resident has a conception that Bogor is a city of tourism and resort. This study shows that Bogor urban identity as historic city only supported by a physical artifact of the empire and colonial periods alone. Activities and perceptions of people living in Bogor unrelated or unsupport the formation of urban identity. To keep the sense of place of Bogor, at least there are two aspects which should be considered which are revitalizing the old city and the development of Transit Oriented Development.
\end{abstract}

Keywords: Bogor city, sense of place, settlement.

\begin{abstract}
ABSTRAK
Kota Bogor memiliki tiga tipologi permukiman yaitu kawasan historis, kawasan pembangunan internal, dan kawasan komuter. Penelitian ini bertujuan untuk mendeskripsikan sense of place di kota Bogor berdasarkan persepsi penduduk yang tinggal di permukiman tersebut.Metode penelitian yang digunakan adalah metode survei dengan menggunakan teknik kuesioner dan observasi lapangan. Variabel penelitian menggunakan tiga komponen pembentuk sense of place yaitu atribut fisik, aktivitas, dan konsepsi. Hasil penelitian menunjukkan bahwa kondisi alam dan peninggalan kolonial masih memiliki kontribusi yang besar dalam menciptakan sense of placekota Bogor. Aktivitas penduduk kota Bogor sebagai komuter ke Jakarta menjadi karakteristik utama aktivitas di kota ini. Walaupun demikian, pada saat akhir pekan sebagian besar penduduk menghabiskan waktu di kotanya sendiri.Konsepsi penduduk terhadap kota Bogor yang terbesar adalah sebagai kota pariwisata dan kota peristirahatan. Penelitian ini menunjukkan identitas perkotaan Bogor sebagai kota bersejarah saat ini hanya ditopang oleh artifak fisik peninggalan zaman kerajaan dan kolonial saja. Aktivitas dan persepsi penduduk yang bermukim di Bogor tidak berhubungan atau menunjang ke terbentuknya identitas tersebut. Untuk tetap menjaga sense of place kota Bogor paling tidak ada dua aspek yang perlu diperhatikan dalam penataan kota Bogor yaitu revitalisasi kota lama dan pengembangan Transit Oriented Development.
\end{abstract}


Kata kunci: kota Bogor, permukiman, sense of place.

\section{PENDAHHULUAN}

Manusia membutuhkan rasa identitas (sense of identity) melalui rasa kepemilikan teritorial atau kelompok tertentu. Proshansky dan Kaminoff (1983) menyatakan bahwa place menyediakan dasar pengalaman manusia dalam keberlanjutan waktu. Individu butuh mengekspresikan rasa memiliki pada entitas atau place kolektif dan identitas individual yang akan didapat melalui perbedaan fisik atau rasa tertentu dalam memasuki kawasan tertentu. Identitas kota sangatlah penting karena kota adalah sebuah tempat di mana orang-orang di dalamnya mengidentifikasi hubungan diri mereka dengan tempat tinggalnya (Tajfel, 1982).

Istilah place menunjukkan ruang
yang bermakna (meaningful) bagi
seseorang. Suatu makna hanya dapat
dirasakan melalui pengalaman dan
interaksi. Jika tidak terdapat pengalaman maka tidak akan timbul sense of place (Cresswell, 2004). Pengalaman bisa didapatkan secara langsung melalui sensasi fisik dari sebuah place atau secara tidak langsung melalui pengetahuan kognitif. Canter (1977) menyatakan bahwa sense of place dapat didefinisikan sebagai unit-unit dari pengalaman di mana aktivitas dan bentuk fisik melebur. Ada tiga komponen yang membentuk sense of place yaitu atribut fisik dari lingkungan, aktivitas yang terjadi di dalamnya, dan konsepsi manusia yang merasakan semua hal di atas.

Moser (2003) menyatakan bahwa place sangat penting peranannya dalam desain urban. Pemahaman tentang kultur dan karakteristik daerah menjadi ciri khas untuk digunakan sebagai salah satu pertimbangan agar penghuni tidak merasa asing dalam lingkungannya. Integrasi kota tidak hanya terletak pada konfigurasi fisik, tetapi integrasi antara aspek morfologi ruang dengan masyarakat atau manusia. Space (ruang) dapat digambarkan sebagai sebuah void fungsional yang berhubungan dengan benda-benda fisik. Space tersebut hanya dapat menjadi place apabila diberi "contextualmeaning" yang berasal dari konten lokal atau regional (Trancik, 1986).

Berdasarkan sejarah, dapat diamati bagaimana dinamika kota dipengaruhi oleh perkembangan masyarakatnya dan demikian pula sebaliknya. Artinya, perkembangan masyarakat terungkap dalam perkembangan kota. Dinamika ini terjadi secara alamiah karena masyarakat yang hidup selalu mempunyai kecenderungan untuk mengekspresikan kehidupan melalui perkembangan kotanya (Castello, 2006). Masalahnya sekarang, kota bukan lagi merupakan wilayah yang tertutup seperti dulu. Transportasi modern telah menyebabkan sirkulasi dan interaksi antar penduduk kota secara leluasa.

Kota Bogor yang dahulu bernama Buitenzorgterletak di provinsi Jawa Barat.Merupakan salah satu kota bernuansa kolonial di Indonesia yang memiliki tata ruang dengan konsep Garden City. Konsep tersebut sampai saat ini masih terlihat khususnya pada bagianbagian kota awal yaitu sekitar Kebun Raya (Sarilestari, 2009).Sebagai bagian dari Jabodetabek, kota Bogor secara riil berperan sebagai sub-urbankota Jakarta sehingga banyak menarik pendatang untuk dipilih menjadi tempat tinggal (dormitorytown). Kota ini tumbuh sebagai kota berbasis pemukiman para pekerja yang mencari nafkah di Jakarta. Hal ini secara nyata terlihat dengan menjamurnya perumahan sejak awal tahun 1990-an. Data tahun 2007 menunjukkan bahwa terdapat 90 perumahan, baik yang dikelola oleh pemerintah maupun pengembang swasta (http://www.kotabogor.go.id).

Kota Bogor dipilih sebagai obyek penelitian karena merupakan kota yang sudah memiliki sejarah panjang dan memiliki karakteristik geografis tersendiri. Kota Bogor saat ini memiliki 3 tipologi permukimanyaitu kawasan historis, kawasan pembangunan internal, dan kawasan komuter. Melalui penelitian tentang sense of placeberbasis persepsi penduduk di permukiman iniakan diketahui elemen-elemen yang menciptakan identitasperkotaan. Hal ini dirasa penting untuk mencegah rusaknya identitas kota- 
kota bersejarah di masa depan oleh pembangunan yang bersifat kapitalistik.

\section{METODOLOGI}

Lokasi penelitian adalah di kota Bogor yang terletak $54 \mathrm{~km}$ sebelah Selatan kota Jakarta. Penelitian ini menggunakan metode surveidengan teknik kuesioner dan observasi lapangan. Pengambilan data untuk kuesioner menggunakan teknik cluster sampling.

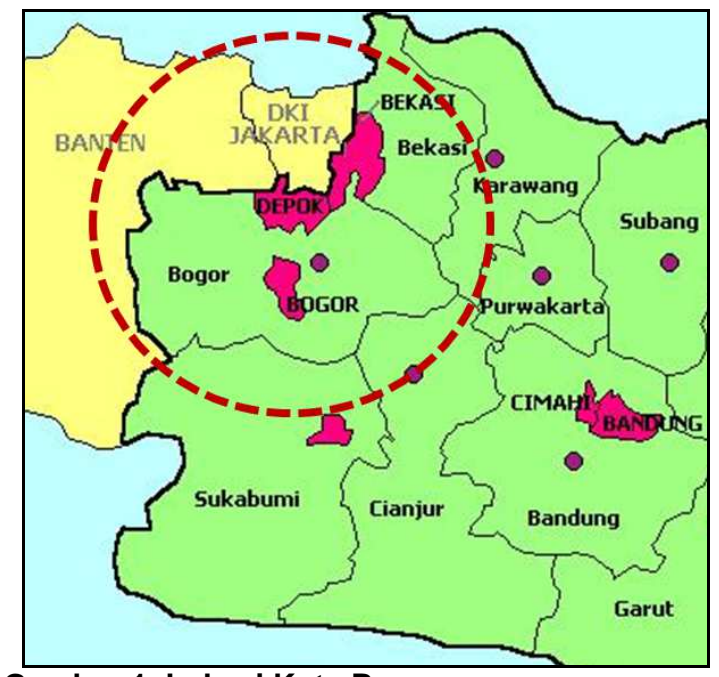

Gambar 1. Lokasi Kota Bogor
(Sumber: http://www.kotabogor.go.id, 2013).

Pemilihan klaster sampel didasarkan pada tiga tipologi kawasan permukiman yang ada di kota Bogor saat ini. Berdasarkan studi literatur dan observasi lapangan ditentukan 3 tipologi kawasanpermukiman (Sopandi, 2003) yaitu:

- Permukiman di kawasan historis (kolonial) dengan klaster sampel yaitu perumahan di Taman Kencana, Surya Kencana, dan Empang.

- Permukiman di kawasan pembangunan ekonomi \& Perdagangan (internal) dengan klaster sampel yaitu perumahan Bantar Jati dan Taman Cimanggu.

- Permukiman di kawasan yang terkait dengan pola komuter (regional) dengan klaster sampel yaitu perumahan Vila Duta dan Bogor Nirwana Residence.

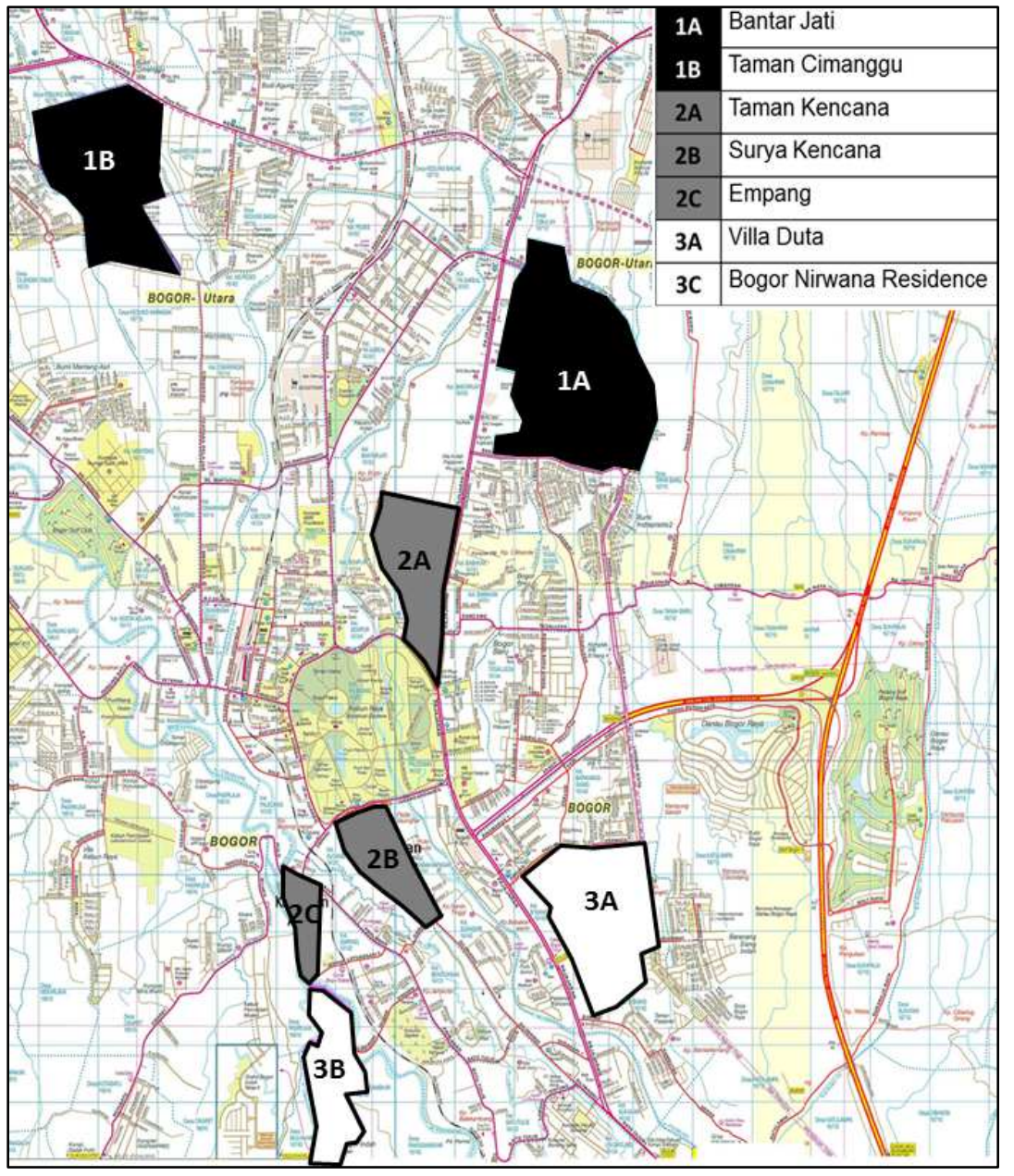


Gambar 2. Klaster Sampel Penelitian

(Sumber: Peneliti, 2013).

atas sistem proporsional sesuai jumlah rumah yang ada di kawasan tersebut. Responden terbesar adalah di perumahan Bantar Jati $(30,4 \%)$ sedang jumlah responden terkecil adalah di kawasan

Untuk mengeksplorasi persepsi penduduk tentang "sense of place" pada kota Bogor, penelitian ini menggunakan variabel tiga komponen pembentuk sense of place(Canter, 1977). Tiga komponen tersebut adalah: (1) atribut fisik dari lingkungan, (2) aktivitas yang terjadi di dalamnya, dan (3) konsepsi dari manusia yang merasakan semua hal tersebut.

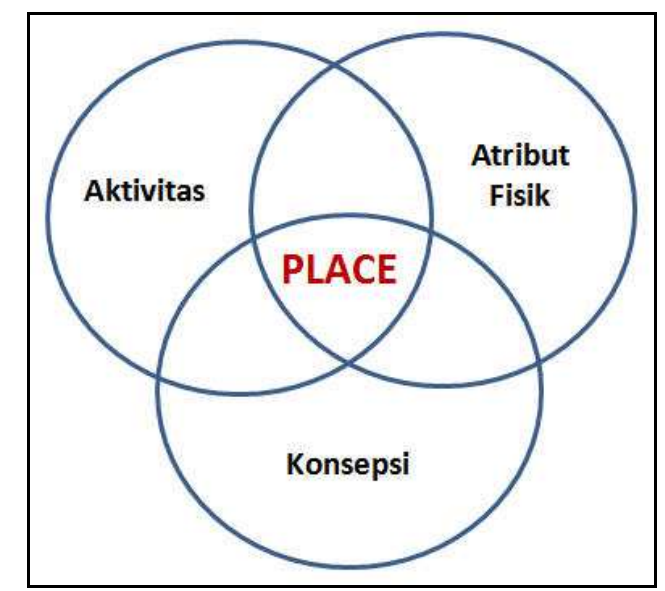

Gambar 3. Komponen Sense of Place (Sumber: Canter, 1977).

Analisis data menggunakan statistik deskriptif dengan menggunakan histogram yang dapat menggambarkan persepsi responden dari masing-masing klaster sampel. Dari analisis didasarkan jawaban terbanyak responden yang dapat mewakili karakteristik penduduk pada masingmasing klastersampel (Cresswell, 2002).

\section{HASIL PENELITIAN DAN}

\section{PEMBAHASAN}

\section{Gambaran Umum Responden}

Jumlah responden

secara

keseluruhan adalah 414 responden. Masing-masing klaster sampel memiliki jumlah responden yang berbeda-beda. Penentuan jumlah responden didasarkan 


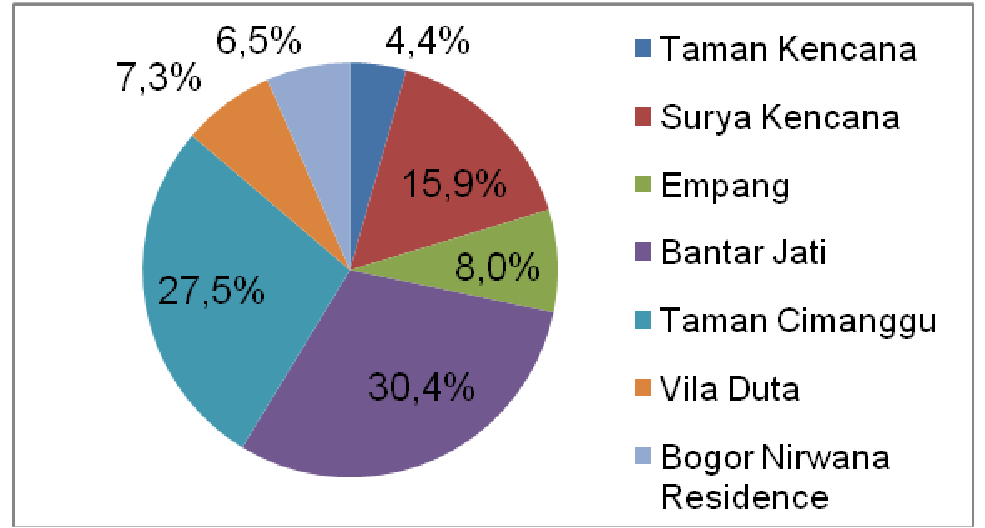

Gambar 4. Jumlah Responden dalam Klaster Sampel (Sumber: Peneliti, 2013).

\section{Atribut Fisik}

Obyek yang menjadi landmark kota Bogor menurut sebagian besar responden adalah Istana dan Kebun raya (53,1\%). Responden terbesar yang menjawab Istana dan Kebun Raya sebagai landmark kota Bogor adalah dari perumahan Taman Kencana (83,3\%), perumahan Surya
Kencana $(89,4 \%)$, perumahan Empang $(54,6 \%)$, dan perumahan Vila Duta (63,3\%). Responden terbesar yang menjawab Tugu Kujang adalah dari perumahan Bantar Jati (55,6\%), perumahan Taman Cimanggu (48,3\%), dan perumahan Bogor Nirwana Residence $(81,5 \%)$.

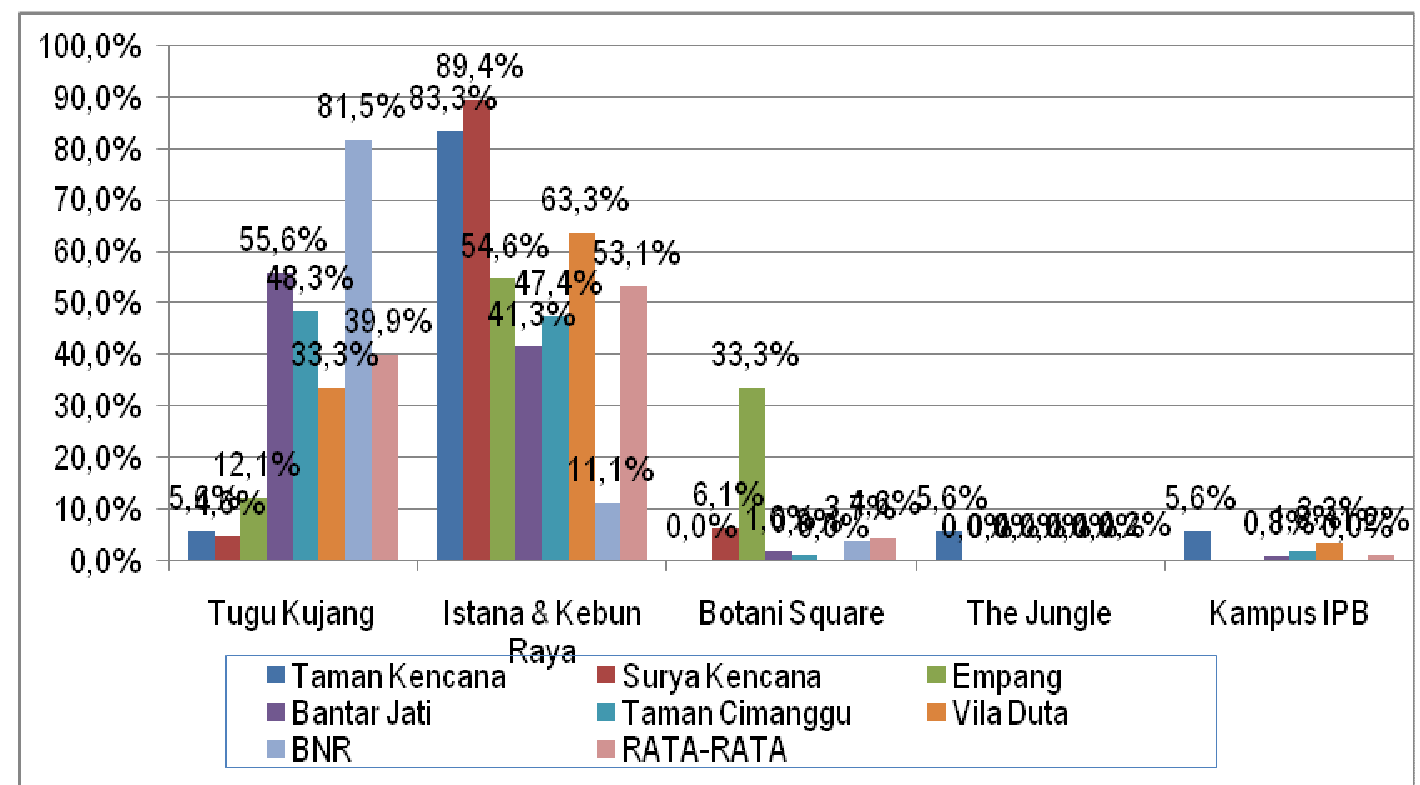

Gambar 5. Landmark kota Bogor

(Sumber: Peneliti, 2013) 


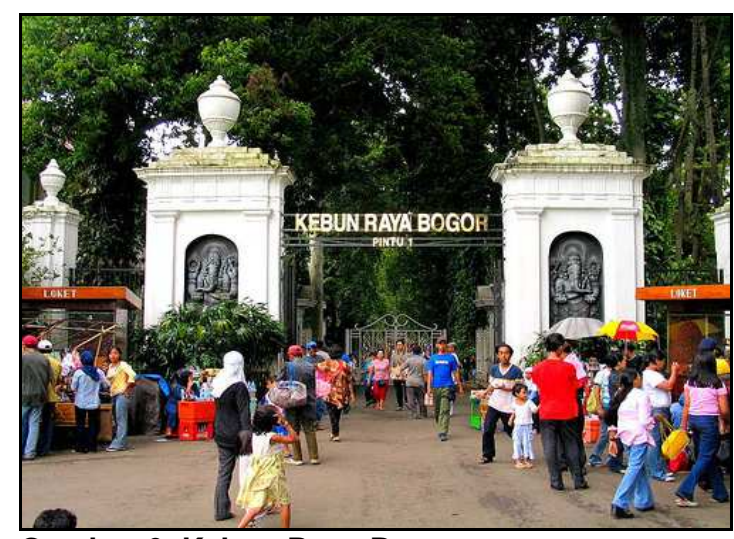

Gambar 6. Kebun Raya Bogor

(Sumber: Peneliti, 2013).

Dari jawaban responden terlihat polarisasi pendapat antara perumahan baru (Bantar Jati, Taman Cimanggu, Vila duta, dan BNR) dan perumahan lama (Taman Kencana, Surya kencana, dan Empang). Pada perumahan lama sebagian besar menyatakan Istana dan Kebun raya sebagai landmark sedang pada perumahan baru sebagian besar menyatakan tugu Kujang sebagai landmark kota Bogor. Sebenarnya kedua jawaban tersebut merepresentasikan simbol sejarah Bogor yang masih ingin dijaga masyarakatnya sebagai identitas kota mereka.

Yang paling disukai di kota Bogor menurut para responden secara umum adalah iklim yang sejuk $(64,7 \%)$. Ini merupakan jawaban terbanyak dari hampir seluruh responden (6 klaster sampel) yaitu perumahan Taman Kencana 38,9\%, perumahan Surya Kencana 90,9\%, perumahan Empang 81,8\%, perumahan Taman Cimanggu 69,3\%, perumahan Vila

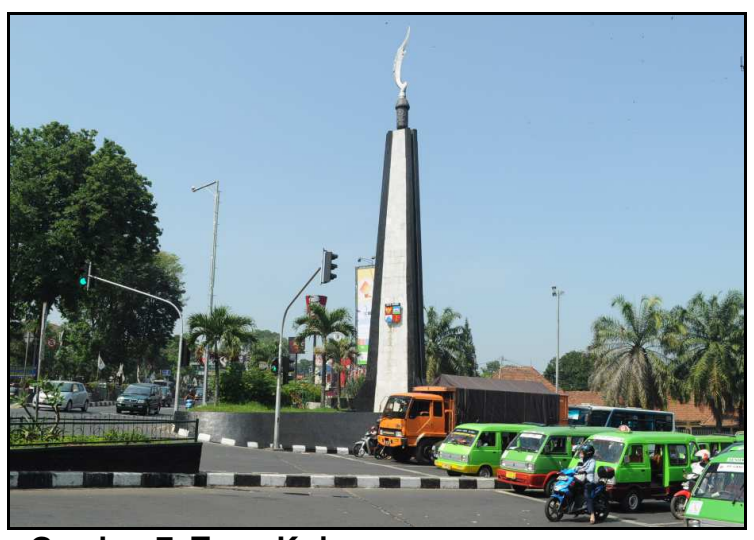

Gambar 7. Tugu Kujang

(Sumber: Peneliti, 2013).

Duta 70,0\%, dan perumahan Bogor Nirwana Residence 88,9\%. Hanya responden dari perumahan Bantar Jati $(46,8 \%)$ yang menjawab terbanyak kota taman (gardencity) sebagai yang paling disukai.

Faktor alam seperti iklim kota Bogor yang sejuk menjadi pilihan mayoritas responden melebihi keunikan kota Bogor sebagai bekas kota kolonial. Walaupun demikian, dengan meluasnya daerah terbangun di kota Bogor saat ini iklim Bogor sudah tidak sesejuk dulu. Bahkan lokasi yang jauh dari rindangnya Kebun Raya sudah terasa panas. Jawaban responden Bantar Jati mengindikasikan hal ini. Responden dari perumahan Bantar Jati sebagian besar tidak memilih iklim yang sejuk sebagai yang disukai di kota Bogor. Hal ini disebabkan letak perumahan mereka yang jauh dari pusat kota lama yaitu wilayah Kebun Raya Bogor. 


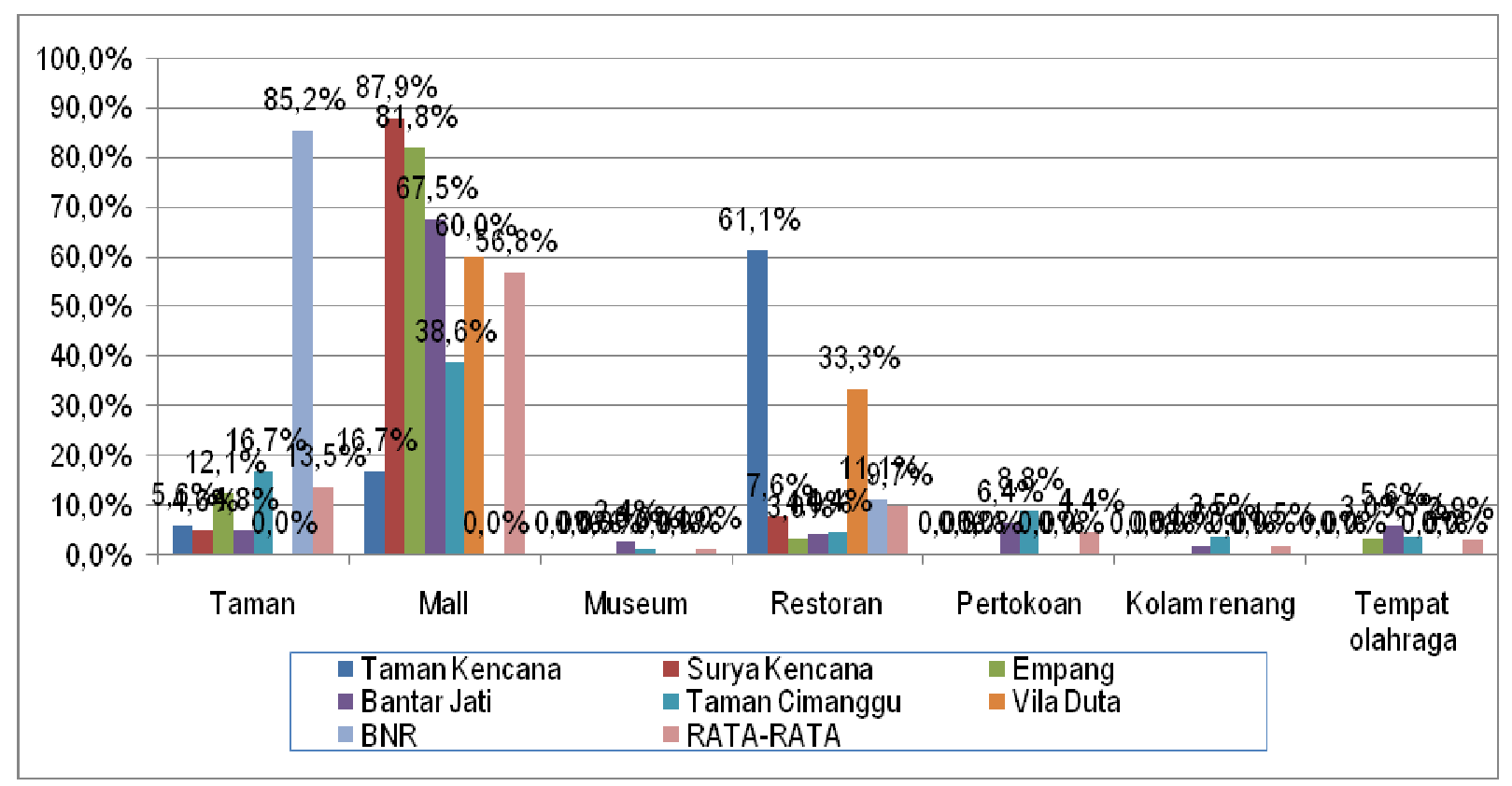

Gambar 8. Tempat Umum yang Sering Dikunjungi di kota Bogor (Sumber: Peneliti, 2013).

Tempat umum yang paling sering dikunjungi di kota Bogor menurut jawaban responden yang terbanyak adalah pusat perbelanjaan mall $(56,8 \%)$. Ada lima klaster yang menjawab mall sebagai jawaban terbanyak, yaitu warga perumahan Surya Kencana (87,9\%), perumahan Empang (81,8\%), perumahan

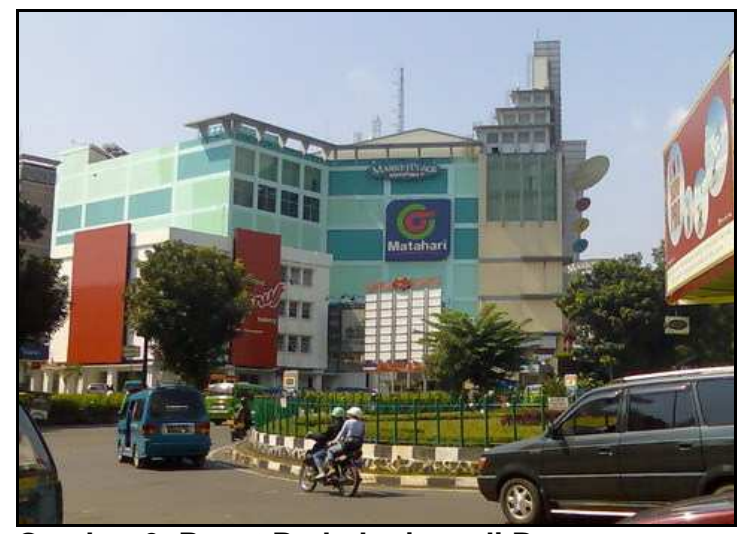

Gambar 9. Pusat Perbelanjaan di Bogor (Sumber: Peneliti, 2013).

Sangat terlihat dari jawaban responden bahwa pusat perbelanjaan modern di kota Bogor memiliki demandyang besar. Faktor gaya hidup perkotaan seperti di Jakarta sudah menyebar di masyarakat Bogor. Yang menarik diperhatikan dari jawaban
Bantar jati $(60,0 \%)$, perumahan Taman Cimanggu $(38,6 \%)$, dan perumahan Vila duta $(56,8 \%)$. Untuk responden dari perumahan Taman Kencana jawaban terbanyaknya adalah restoran $(61,1 \%)$ dan responden dari perumahan Bogor Nirwana Residence adalah taman (85,2\%).

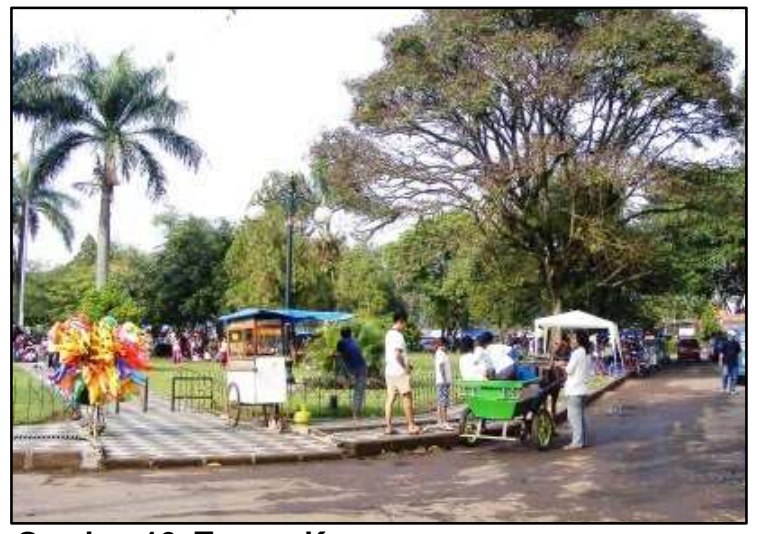

Gambar 10. Taman Kencana

(Sumber: Peneliti, 2013).

responden ini adalah bahwa yang sangat suka mengunjungi mal adalah responden yang berpenghasilan menengah ke bawah. Responden berpenghasilan tinggi seperti di perumahan Taman Kencana dan perumahan BNR lebih memilih ke restoran atau taman-taman yang menjadi fasilitas 
lingkungan perumahan mereka. Hal ini bisa disebabkan oleh banyak hilangnya ruang terbuka publik di permukiman untuk masyarakat berpenghasilan menengah ke bawah.

\section{Aktivitas}

Dari hasil tabulasi dan perhitungan kuesioner diketahui bahwa responden yang bekerja atau sekolah di Jakarta ratarata adalah $38,5 \%$. Klaster yang relatif tinggi jumlahnya adalah di perumahan Taman Kencana $(57,1 \%)$, perumahan Vila Duta (52,9\%), dan perumahan Bogor Nirwana Residence (47,6\%). Yang menengah adalah di perumahan Bantar Jati $(35,5 \%)$ dan perumahan Taman Cimanggu (31,0\%), sedang yang rendah adalah perumahan Surya Kencana $(19,6 \%)$ dan perumahan Empang $(25,9 \%)$.

Dari jawaban responden terlihat bahwa penduduk yang banyak beraktivitas di Jakarta adalah para pendatang yang berpenghasilan tinggi. Tentunya ini berhubungan juga dengan konsep dormitorytown yang memerlukan biaya untuk sarana transportasi. Penduduk perumahan Surya kencana dan perumahan Empang sebagian besar asli Bogor dan berpenghasilan menengah ke bawah. Mereka secara turun menurun banyak melakukan aktivitas di dalam kota Bogor.

Pilihan alat (moda) transportasi terbanyak yang digunakan responden jika menuju Jakarta adalah KRL Jabotabek $(50,0 \%)$. Jawaban terbanyak kedua adalah menggunakan mobil pribadi $(43,3 \%)$ sedang jawaban terbanyak ketiga adalah menggunakan bis umum $(10,1 \%)$. Terdapat empat klaster sampel yang menjawab terbanyak menggunakan KRL yaitu warga perumahan Surya Kencana (72,7\%), perumahan Empang (93,9\%), perumahan Bantar jati $(53,2 \%)$ dan perumahan Taman Cimanggu (49,1\%). Tiga klater sampel lain yaitu perumahan Taman Kencana $(55,6 \%)$, perumahan Vila Duta $(90,0 \%)$, dan perumahan Bogor Nirwana Residense (100\%) menjawab terbanyak menggunakan mobil pribadi.

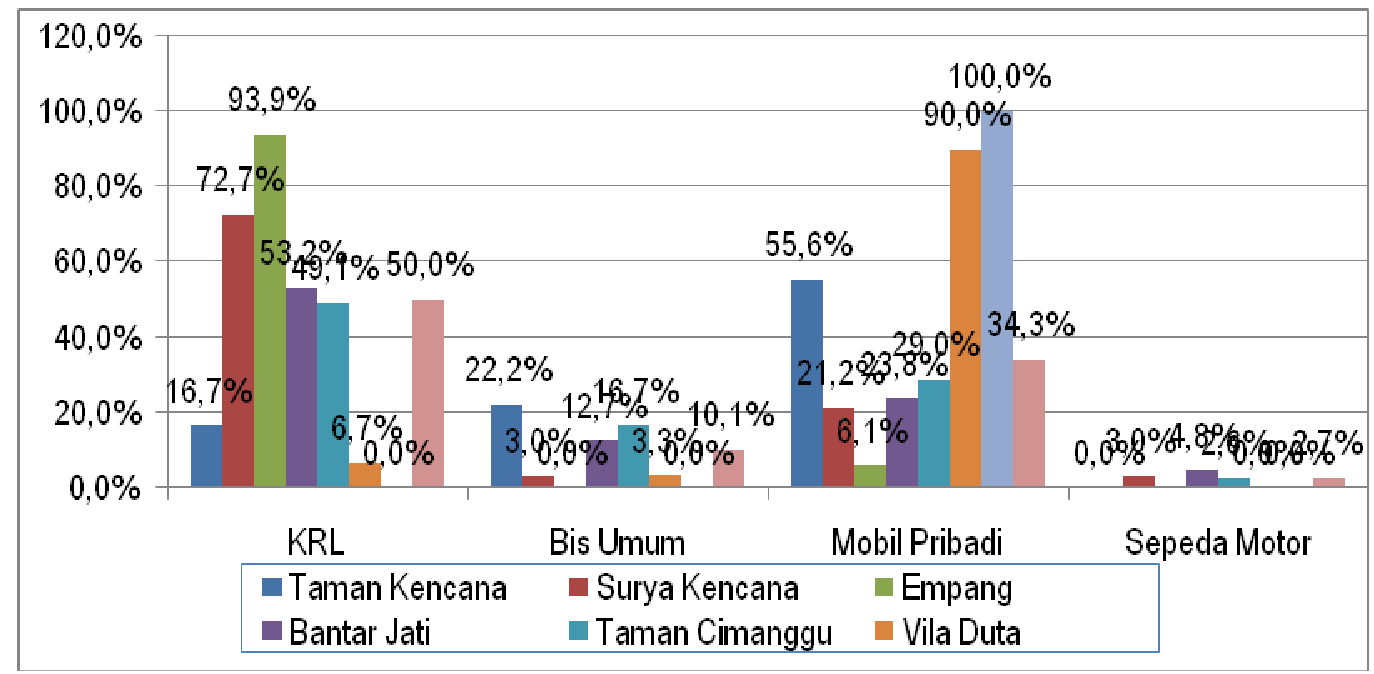

Gambar 11. Moda Transportasi ke Jakarta

(Sumber: Peneliti, 2013).

Terdapat dua jawaban terbanyak yang berimbang mengenai alasan utama dalam memilih alat transportasi ke Jakarta yaitu faktor kenyamanan $(30,9 \%)$ dan faktor kecepatan (30,4\%). Jawaban ketiga terbanyak adalah faktor murah (28,3\%). Responden yang menjawab kebersamaan dengan teman atau keluarga hanya $10,4 \%$.Klaster sampel yang terbanyak menjawab karena alasan kenyaman adalah warga perumahan Taman Cimanggu (35,1\%), perumahan Vila Duta $(76,7 \%)$ dan perumahan Bogor Nirwana Residence (51,9\%) sedang yang terbanyak menjawab karena alasan cepat adalah warga perumahan Surya Kencana $(55,6 \%)$ dan perumahan Empang (45,5\%). Satu-satunya klaster sampel yang menjawab terbanyak karena alasan murah adalah warga perumahan Surya Kencana 
(48,5\%). Responden ekonomi menengah ke atas akan memilih moda transportasi yang cepat dan murah misalnya $\mathrm{KRL}$ kelas ekonomi sedang yang ekonomi menengah ke atas akan memilih faktor kenyamanan.

Secara keseluruhan jawaban terbanyak untuk tempat liburan akhir pekan adalah di kota Bogor (87,2\%). Hampir seluruh klaster sampel menjawab

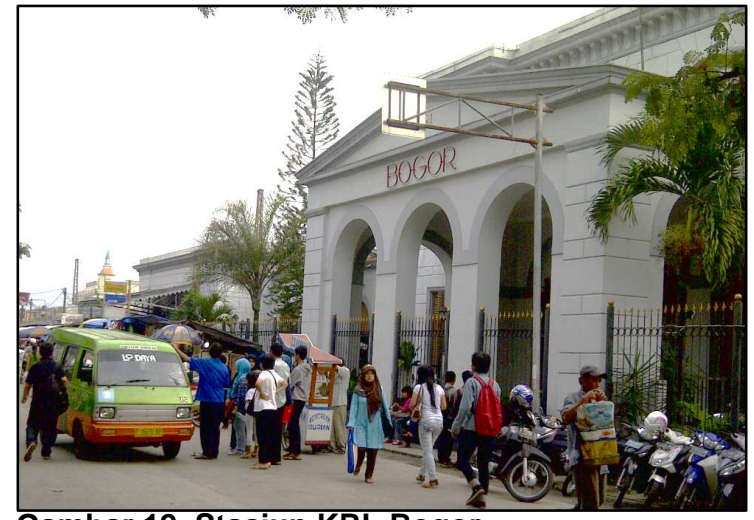

Gambar 12. Stasiun KRL Bogor

(Sumber: Peneliti, 2013).

Pada saat akhir pekan (weekend) sebagian besar responden menghabiskan waktu di kotanya sendiri yaitu Bogor. Hanya pada akhir pekanlah mereka bisa menikmati kotanya dengan leluasa. Mobilitas penduduk Bogor pada saat libur akhir pekan lebih banyak bersifat internal di kota Bogor. Ini merupakan ungkapan kerinduan terhadap tempat tinggal mereka yang tidak banyak bisa dinikmati pada saat hari kerja.

Pada akhir pekan justru banyak penduduk Jakarta yang berkunjung ke Bogor. Mereka banyak mengunjungi tempat-tempat wisata, pusat-pusat kuliner, maupun tempat-tempat penjualan produk khas Bogor. Campuran pergerakan penduduk Bogor dan pendatang dari Jakarta menyebabkan banyak kemacetan di pusat kota Bogor misalnya pada kawasan Pecinan di jalan Surya Kencana. ini sebagai yang terbanyak kecuali di perumahan Bogor Nirwana Residence yang terbanyak menjawab tempat lain $(51,9 \%)$. Jawaban tempat lain ini menunjukkan bahwa responden menghabiskan libur akhir pekan dengan di luar kota Bogor misalnya ke daerah Puncak, Bandung, dan lain-lain.

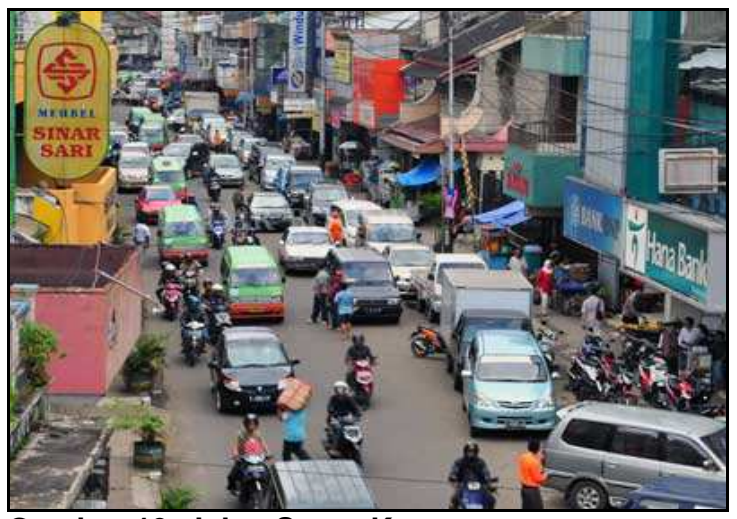

Gambar 13. Jalan Surya Kencana

(Sumber: Peneliti, 2013).

\section{Konsepsi}

Citra (image) kota Bogor menurut konsepsi terbanyak dari para responden adalah sebagai kota pariwisata $(32,6 \%)$. Walaupun demikian, ada dua jawaban lain yang cukup banyak pemilinnya yaitu kota peristirahatan (26,6\%) dan kota pendidikan (23,4\%). Responden terbanyak yang menjawab kota pariwisata adalah dari perumahan Surya Kencana (45,5\%), perumahan Empang (78,8\%), perumahan Bantar Jati $(31,0 \%)$, dan perumahan Vila Duta (46,7\%). Responden terbanyak yang menjawab kota peristirahatan adalah dari perumahan Taman Kencana $(77,8 \%)$ dan perumahan Bogor Nirwana Residence $(77,8 \%)$. Sedangkan yang terbanyak menjawab kota pendidikan adalah responden dari perumahan Taman Cimanggu (50,9\%). 


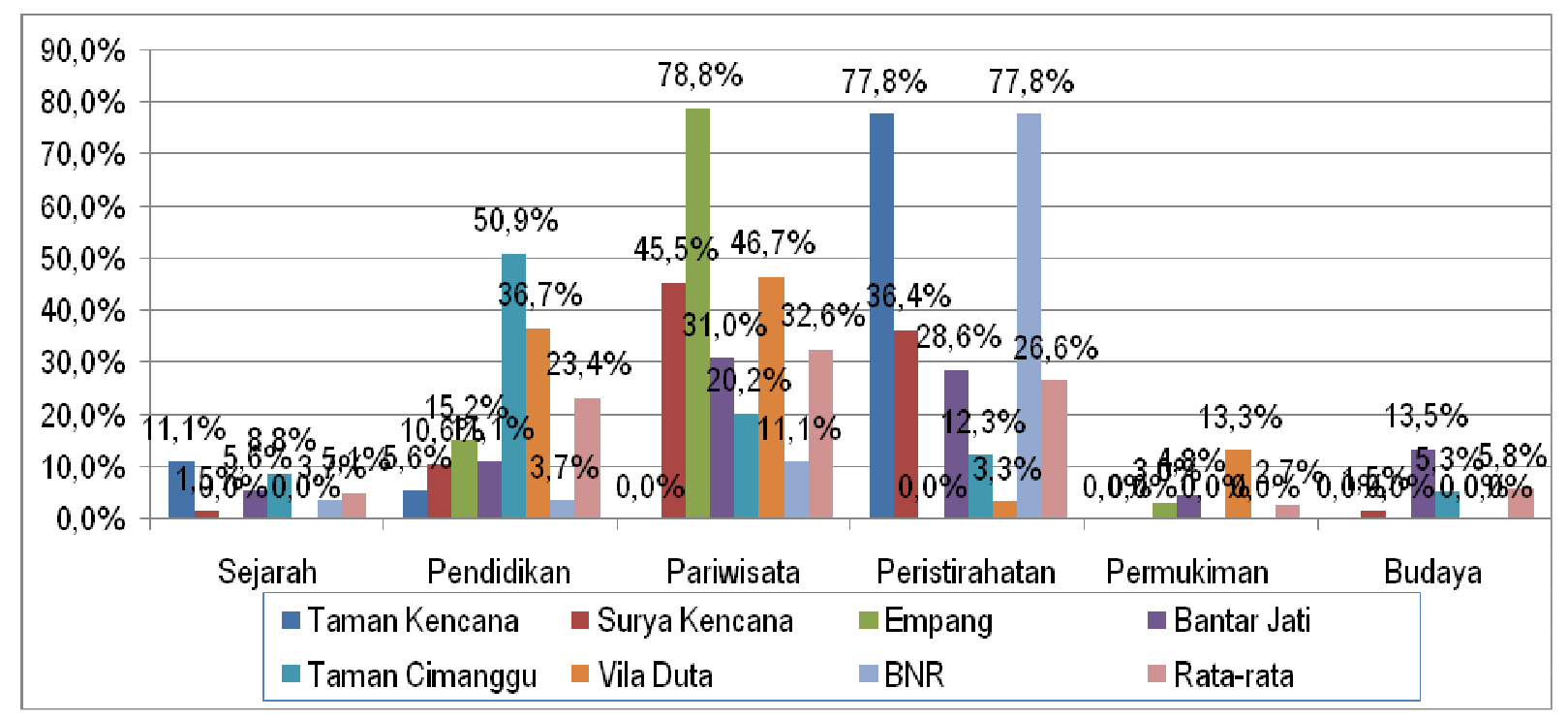

Gambar 14. Konsepsiterhadap Kota Bogor

Sumber: Peneliti, 2013.

Konsepsi kota Bogor sebagai kota pariwisata bertumpu pada sumber daya alam yang dimiliki. Dengan potensi pariwisata ini Bogor mampu menarik pengunjung dari luar terutama penduduk Jakarta untuk datang. Bogor sebagai kota peristirahatan lebih dirasakan oleh para komuter atau orang Jakarta yang memiliki rumah peristirahatan di Bogor. Antara aktivitas pariwisata dan peristirahatan ini

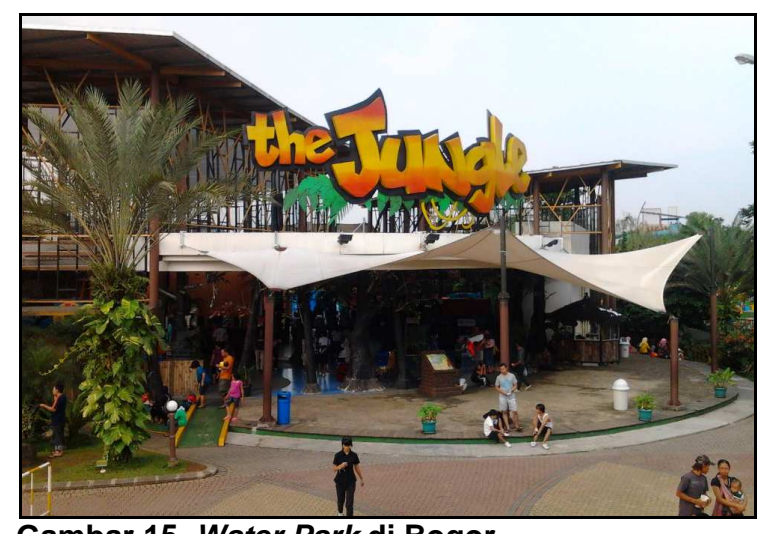

Gambar 15. Water Park di Bogor

(Sumber: Peneliti, 2013).

Sebagian besar responden $(84,3 \%)$ menyatakan bahwa mereka lebih senang dikenal sebagai orang Bogor. Hampir seluruh klaster sampel terbanyak memilih jawaban ini, hanya responden dari perumahan Bogor Nirwana Residence yang menjawab lebih senang dikenal sebagai orang Jakarta $(33,3 \%)$. Untuk jawaban lain, responden yang menjawab berhubungan karena keduanya bersifat menyegarkan baik untuk penduduk Bogor maupun orang Jakarta yang berlibur di Bogor. Untuk karakter kota Bogor sebagai kota pendidikan sangat dipengaruhi karena adanya kampus IPB yang berskala nasional. Mahasiswa IPB tidak hanya dari kota Bogor tetapi dari seluruh provinsi di Indonesia sehingga banyak orang melihat Bogor sebagai kota pendidikan.

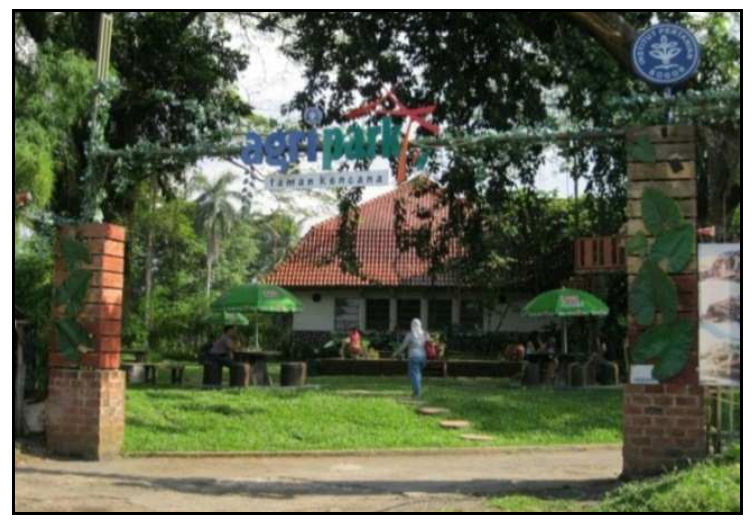

Gambar 16. Cafedi Taman Kencana

(Sumber: Peneliti, 2013).

lebih senang dikenal sebagai orang Bogor sekaligus Jakarta hanya $6,5 \%$, sedang yang senang dikenal sebagai orang Jakarta hanya $4,1 \%$.

Dari jawaban mayoritas responden tercermin adanya kebanggaan (selfesteem) terhadap kota Bogor. Mereka lebih memilih dikenal sebagai orang Bogor walaupun banyak melakukan aktivitas di 
Jakarta. Untuk responden dari perumahan Bogor Nirwana Residence menjadi perkecualian karena banyak dari mereka yang memiliki rumah di Bogor hanya sebagai rumah kedua untuk beristirahat atau investasi. Di samping itu mereka juga tidak memiliki ikatan sosial yang kuat.

\section{KESIMPULAN DAN SARAN \\ Kesimpulan}

Kota Bogor telah melalui beberapa tahap perkembangan yaitu dari masa Kerajaan, masa kolonial, masa kemerdekaan, sampai menjadi kota penyangga megapolitan Jakarta. Dari hasil penelitian tentang sense of placeberbasis persepsi penduduk di permukiman inidiketahui Kondisi alam yang sejuk merupakan suatu karakteristik yang sangat disukai oleh penduduknya sampai saat ini.Artifak peninggalan kolonial juga masih memiliki kontribusi yang besar dalam menciptakan identitas fisik kota Bogor.

Walaupun kota Bogor memiliki
banyak artifak sejarah tetapi keberadaannya tidak berpengaruh terhadap identitas perkotaan dari segi aktivitas penduduknya. Bangunanbangunan bersejarah baik zaman Kerajaan maupun kolonial tidak menarik untuk dikunjungi penduduk Bogor. Mereka lebih suka mengunjungi pusat-pusat perbelanjaan modern (mall) atau tamantaman kota.

Mobilitas penduduk kota Bogor sebagai komuter ke Jakarta menjadi salah satu karakteristik sense of placedari segi aktivitas perkotaan. Fenomena komuter di Kota Bogor terlihat dari tingginya jumlah perjalanan menuju Jakarta dan kembali ke Bogor setiap hari kerja. Penduduk dengan ekonomi menengah ke bawah akan memilih moda transportasi yang cepat dan murah yaitu KRL sedang yang ekonomi menengah ke atas akan memilih mobil pribadi dengan pertimbangan faktor kenyamanan.Pada saat akhir pekan (weekend) sebagian besar penduduk menghabiskan waktu di kotanya sendiri.Mobilitas internal penduduk Bogor ditambah kunjungan penduduk Jakarta di akhir pekan menyebabkan kota Bogor menjadi sangat padat dan terjadi banyak kemacetan.
Konsepsi penduduk terhadap kota Bogor yang terbesar adalah sebagai kota pariwisata dan kota peristirahatan. Sense of place sebagai kota wisata dan peristirahatan ini sangat berhubungan dengan karakteristik iklim dan potensi alam yang dimiliki kota Bogor. Jati diri dan kebanggaan sebagai penduduk Bogor masih kuatwalaupun banyak penduduk Bogor yang melakukan aktivitas sehariharinya di Jakarta. Di lain pihak faktor sejarah kota Bogor kurang berpengaruh terhadap persepsi identitas penduduknya.

Secara umum dapat disimpulkan bahwa identitas perkotaan Bogor sebagai kota bersejarah saat ini hanya ditopang oleh artifak fisik peninggalan zaman kerajaan dan kolonial saja. Aktivitas dan persepsi penduduk yang bermukim di Bogor tidak berhubungan atau menunjang ke terbentuknya identitas tersebut. Fenomena ini menunjukkan sudah mulai hilangnya sense of place atau "genius loci"pada kota Bogor. Kondisi ini akan bertambah parah jika tidak cepat diperbaiki mengingat fungsi kota Bogor sebagai daerah penyangga (hinterland) ibukota Jakarta.

\section{Saran}

Posisi kota Bogor sebagai kota satelitnya Jakarta menyebabkan pembangunan fisik yang pesat. Apabila pembangunan kota Bogor tidak diarahkan dengan baik maka identitas kota yang sudah ada akan pudar atau berubah. Untuk tetap menjaga sense of place kota Bogor paling tidak ada 2 aspek yang perlu diperhatikan dalam penataan kota Bogor yaitu revitalisasi kota lama (ex-kolonial) dan pengembangan Transit Oriented Development (TOD).

Untuk dapat menjaga identitas kota Bogor, kawasan kota lama harus tetap hidup dan terpelihara. Dari segi revitalisasi kota lama (kolonial), sebaiknya dibuatkan regulasi dan desain urban yang tidak tumpang tindih dengan pembangunan baru. Sebaiknya dilakukan revitalisasi pada bangunan-bangunan dan lingkungan peninggalan kota kolonial dengan melakukan alih fungsi yang sesuai dengan tuntutan kebutuhan masyarakat Bogor saat ini. Beberapa fungsi baru harus disuntikkan ke daerah ini sebagai 
generator aktivitas sehingga kota lama tidak mati. Bangunan tua tidak harus menjadi museum tetapi bisa dijadikan pusat perbelanjaan atau restoran tanpa merusak bangunan aslinya.

Kota Bogor yang sudah memiliki sarana $\mathrm{KRL}$ sejak dahulu seharusnya didesain menerapkan konsep TOD. Pengembangan kawasan menggunakan TOD berorientasi pada titik-titik transit yaitu lokasi di mana angkutan umum massal berhenti (Calthorpeer\&Fulton, 2001). Sebaiknya dibuat pusat-pusat transportasi penghubung (feeder) yang dilengkapi dengan penitipan kendaraan. Sistem ini sebaiknya menggunakan bus besar dan tidak lagi menggantungkan pada mobil kecil (angkot) sehingga kemacetan dapat diminimalisir. Daerah sekitar titik transit utama maupun sekunder bisa didesain sebagai daerah komersial, sedangkan daerah hunian bisa diletakkan pada jarak yang lebih jauh.

\section{DAFTAR PUSTAKA}

Calthorpe, Peter \&Fulton, William. 2001. The Regional City - Planning of theEnd of Sprawl. Washington DC: Island Press.

Canter, D. 1977. The Psychology of Place. London: Architectural Press.

Castello L. 2006. "City \& Time and Places: Bridging the Concept of Place to Urban Conservation Planning." City \& Time, vol. 2.

Cresswell John W. 2002. Research Design: Qualitative, Quantitative, and Mix Methods Approaches. California: SagePublications.

http://www.kotabogor.go.id [diakses 12 Desember 2014].

Moser, Gabriel, et.al. (eds.). 2003. People, Places, andSustainability. Seatle: Hogrefe\&HuberPublishers.

Proshansky, H, Fabian A., \&Kaminoff, R. 1983. "Place Identity: Physical WorldSocialization of theSelf." Journal of EnvironmentalPsychology, vol. 3

Sarilestari, Wulan. 2009. Rencana Pelestarian Konsep Garden City Kota Bogor Lama (Buitenzorg) Jawa Barat, (Tesis Magister, tidak diterbitkan). Bogor: Departemen Arsitektur Lanskap, Institut Pertanian Bogor.
Sopandi, Setiadi. 2003. "Arsitektur Kota Bogor: Membaca Kembali Karakter Lingkungan Kota Kolonial." Kompas, 21 September.

Tajfel, H. $1982 . \quad$ Social IdentityandlntergroupRelations.

Cambridge: CambridgeUniversity Press.

Trancik, Roger. 1986. Finding Lost Space. New York: Van NostrandReinhold Company. 